\title{
The Use of Snowball Technique in Teaching Writing Skill in EFL Classroom
}

\author{
Rina Indriani
}

SMK NW Pancor, Indonesia

Correspondence: Rina Indriani, Indonesia. e-mail: rinaindriyanie@gmail.com

Received: November 30, 2018

doi: 10.29408/veles.v3i1.1051.g725

\author{
Accepted: Februari 07, $2019 \quad$ Online Published: April 15, 2018 \\ URL: http://dx.doi.org/10.29408/veles.v3i1.1051.g725
}

\begin{abstract}
This study aims at investigating the use of Snowball technique in teaching writing skill in EFL Classroom. Designed as pre-experimental research with pretest-posttest design, the sample of this research was 21 of 76 students of the tenth grade of SMK NW Pancor in the school year 2017-2018. Random sampling technique was used in determining the sample of the study. Writing test was the instrument used to collect the data. The data were then analyzed by using descriptive statistic and paired sample t-test to test the hypothesis. Based on the result of study, the mean score of the pre-test was 36.38 while in the post-test, it was 60.76; It means that the mean score of the post-test was higher than the mean score of pre-test. After submitting the data to a paired sample t-test, the present researcher found that the significance (2-tailed) value level of analyzed data was 0.00 which was lower than 0.05 , so the alternative hypothesis (Ha) of this study was accepted. It implies that Ssnowball ttechnique was significantly effective in teaching writing recount text. It is suggested that English teacher use Ssnowball technique as an alternative technique in teaching writing on recount text.
\end{abstract}

Keywords: Snowball technique, writing skill

\section{Introduction}

Language is a key element for human life, this is because with the language we can interact with each other and it can be the resource for social life. So language is means of communiation that is used in social community and has important roles in social interaction, because a language can be used if it can be understand each other. People use it to express their need, feeling, and attitude. If the language does not exist then one is unable to convey the intent and also the goal, which will eventually arise silence that produce nothing.

As we know that one of the linternational languages is English which is used as a means of communications. Thus, people all over the world have used English either in the formal and informal situation. Since English is an International language, it plays an important role, especially to the students in all levels. The quality of human resources is also determined by 
this mastery of language. It is evident that the requirement of knowing both oral and written English is frequently advertised in job vacancy of many daily newspapers.

Indonesia is one of the developing country has also set its educational curriculum which include the teaching of English as a foreign language which is studied from junior high school up to the university level. In the Curriculum of 2013 for Senior High School, learning English is not only in the class but also at home and society. Teachers are not only learning source, they must make the learning process more interesting for students because students must active in exploring many sources for increasing their knowledge.

In learning English, there are four skills which are necessary to be mastered by the learners. Those skills are listening, speaking, reading, and writing. Among those language skills, it has been considered that writing is one of some skills that should be acquired by the students. Writing is one of the most difficult skill of English, productive skill in the written mode and also has powerful means of communication, it is indirect communication which needs to be done skillfully, however, good writing is also is one of the most difficult and complex skills especially if the novice writer never tries to force his imaginations about anything and write down his bright ideas.

According to Urquhart and Monette (2005), "writing is a process of exploration that offers benefits to students and content area teachers alike. As students write to make their ideas clear and comprehensible, they experience the fun of discovery, and so do their teachers". Historically, writing was a product skill for certain people. Writing skill as said by Brown (2000, p. 335) is "a written product which is completed after the process of thinking, planning, drafting, and revising and also demands efforts and specialized skills of generating ideas, organizing them coherently, making use of the discourse markers and the rhetorical conventions, putting all of them into one, revising the content for a clearer meaning, and editing for accurate grammar into a final product".

In learning four language skills, writing has received as great emphasis in teaching and learning process, in receive the great attention compared with the other skill. In this case the students are expected to be able to mastery the writing skill, through some kinds of texts such as procedure, narrative, descriptive, recount, report and procedure text which are called genres. Thus the researcher emphasizes to choose one of the genre is that recount text. The main objective is to make the writing become easier to learn for the students.

According to Ayu Sonia (2016, p. 8), "recount is a text that tells about past experience or events that can be based on the author's personal or historical events". This type of text is chosen as means in which the students write. Writing recount text means that the students are able to develop writing skills of the type of text or genre in the form of recount. Recount text is one of genre that tells of an event that has occured or experienced in the past. Based on these lessons, ideally the students are able to create shaped text because students writes an idea that they experience in their lives.

The material of English subject is very complex and variety, so the teachers should apply the suitable technique in order to achieve the teaching purposes easily and has good preparation for teaching and learning process. By using suitable techniques as an alternative way to help the teacher, the students are expected to write well. The implementation of 
technique in teaching also encourages students to study harder, so the researcher tried to find the easiest way to teach the students in order to achieve the target of learning process easier. Thus, dealing with these problems, the researcher tried to use the Snowball technique so that all students prepare themselves to write, and they could participate. This technique is allegedly able to help create conducive learning; active, creative, and fun learning is using the Snowball technique.

According to Henny Susanti (2016, p.119), "using Snowball technique could help to increase students' activities in learning. Technique of snowball throwing is a teaching technique for cooperative learning which allows students to work together in groups, pay full attention to each other, and allow each other to speak and to share information in groups and begin a collaboration process with those around them to consider their thoughts on the same question and the technique is creative and fun". Therefore, the present researcher completely believes that Snowball technique is an effective technique in teaching and learning process and increasing students' ability in writing. The use of Snowball throwing is hoped can solve the problem of the students in the classroom, especially when they learn about writing. Their problems are they do not have high motivation and do not get some ideas when they are asked to write.

Based on the phenomenon explained previously, the researcher investigated the use of Snowball technique in teaching writing on recount text for the tenth grade students of SMK NW Pancor in the school year 2017-2018.

\section{Method}

The method used in this study was a pre experimental design by using one class as experiment without control group. It was called one group pre-test and post-test design. It aimed at finding out the effectiveness of Snowball technique in teaching writing on recount text for the tenth grade students of SMK NW Pancor in the school year 2017-2018.

\subsection{Participants}

The target population of this study was all of the tenth grade students of SMK NW Pancor which consisted of 3 classes. Thus, the number of the population of this study was 76 students. The researcher took one class as a sample, the researcher used random sampling technique to determine the class as the sample and the researcher got X Jasa Boga as the sample..

\subsection{Data Collection}

\subsubsection{Instrument of Collecting Data}

The instrument which was used in this research was a test. The researcher used a test in the form of subjective test. In this case, the students were asked to write a recount text and the result of students' writing were analyzed using analytical scoring rubric proposed by Brown (2003) including the content, organization, vocabulary, grammar, and mechanicc. In detail, the criteria of evaluation are as follows: 
Table 1. Analytic scale for rating composition tasks

\begin{tabular}{|c|c|c|}
\hline Categories & Score & Criteria \\
\hline \multirow[t]{5}{*}{ Content } & 5 & $\begin{array}{l}\text { Excellent to good: essay addresses the assigned topic, the } \\
\text { ideas are concerete and throughly developed, no extraneous } \\
\text { material, essay reflect thought }\end{array}$ \\
\hline & 4 & $\begin{array}{l}\text { Good to adequate: essay addresses the issues but misses } \\
\text { some points; ideas could be more fully developed. }\end{array}$ \\
\hline & 3 & $\begin{array}{l}\text { Adequate to fair : development of ideas not complete or } \\
\text { essay is somewhat off the topics, paragraphs are not } \\
\text { divided exactly right }\end{array}$ \\
\hline & 2 & $\begin{array}{l}\text { Unacceptable-not : ideas incomplete, essay does not reflect } \\
\text { careful thinking or was hurriedly written, inadequate rffort } \\
\text { in area of content. }\end{array}$ \\
\hline & 1 & $\begin{array}{l}\text { College-level work : essay is completely inadequate and } \\
\text { does not reflects college-level work, no apparent effort to } \\
\text { consider the topic carefully. }\end{array}$ \\
\hline \multirow[t]{5}{*}{ Organization } & 5 & $\begin{array}{l}\text { Excellent to good: appropriate title, effective introductory } \\
\text { paragraph, topic is stated. }\end{array}$ \\
\hline & 4 & $\begin{array}{l}\text { Good to adequate: adequate title, introduction, and } \\
\text { conclusion, body of essay is acceptable but some evidence } \\
\text { may be lacking, some ideas are not fully developed. }\end{array}$ \\
\hline & 3 & $\begin{array}{l}\text { Adequate to fair : mediocre or scant introduction or } \\
\text { conclusion, problems with the order of ideas in body, the } \\
\text { generalization may not be fully supported by the evidence } \\
\text { given. }\end{array}$ \\
\hline & 2 & $\begin{array}{l}\text { Unacceptable-not : shaky or minimally recognizable } \\
\text { introduction, organization can barely be seen, severe } \\
\text { problems with ordering of ideas, lack of supporting } \\
\text { rvidence, conclusion weak or illogical. }\end{array}$ \\
\hline & 1 & $\begin{array}{l}\text { College-level work : absence of introduction or conclusion } \\
\text { no apparent, organization of body, severe lack of } \\
\text { supporting, writer has no made any effort to organize the } \\
\text { composition. }\end{array}$ \\
\hline \multirow[t]{2}{*}{ Grammar } & 5 & $\begin{array}{l}\text { Excellent to good : native- like fluency in English } \\
\text { grammar, correct use of relative clauses, prepositions, } \\
\text { modals, articles, verb forms, and tense sequencing, no } \\
\text { fragments or run-on sentences }\end{array}$ \\
\hline & 4 & $\begin{array}{l}\text { Good to adequate : advanced proficiency in English } \\
\text { grammar, some grammar problems do not influence } \\
\text { communication, although the reader is aware of them, no } \\
\text { fragments or run-on sentences }\end{array}$ \\
\hline
\end{tabular}




\begin{tabular}{|c|c|c|}
\hline & 3 & $\begin{array}{l}\text { Adequate to fair : ideas are getting through to the reader, } \\
\text { but grammar problems are apparent and have a negative } \\
\text { effect on communication, run-on sentences or fragments } \\
\text { present. }\end{array}$ \\
\hline & 2 & $\begin{array}{l}\text { Unacceptable-not : numerous serious grammar problems } \\
\text { interfere with communication of the writer's ideas, } \\
\text { grammar review of some areas clearly needed, fifficult to } \\
\text { read sentences. }\end{array}$ \\
\hline & 1 & $\begin{array}{l}\text { College-level work :Severe grammar problems interfere } \\
\text { greatly with the message, reader can not understand what } \\
\text { the writer was trying to say, unintelligible sentence } \\
\text { structure. }\end{array}$ \\
\hline \multirow[t]{5}{*}{$\begin{array}{l}\text { Mechanics } \\
\text { (punctuation, } \\
\text { spelling) }\end{array}$} & 5 & $\begin{array}{l}\text { Excellent to good: correct use of English writing } \\
\text { conventions, left and right margins, all needed capitals, } \\
\text { paragraphs indented, punctuation and spelling, very neat. }\end{array}$ \\
\hline & 4 & $\begin{array}{l}\text { Good to adequate : some problems with writing } \\
\text { conventions or punctuation, iccasional spelling errors, left } \\
\text { margin correct, paper is neat and legible. }\end{array}$ \\
\hline & 3 & $\begin{array}{l}\text { Adequate to fair: Uses general writing conventions but has } \\
\text { errord, spelling problems distract reader, punctuation errors } \\
\text { interfere with ideas. }\end{array}$ \\
\hline & 2 & $\begin{array}{l}\text { Unacceptable-not: serious problems with format of paper, } \\
\text { parts of essay not legible, errors in sentence punctuation } \\
\text { and final punctuation, unacceptable to educated readers. }\end{array}$ \\
\hline & 1 & $\begin{array}{l}\text { College-level work : complete disregard for English } \\
\text { writing conventions, paper illegible, obvious capitals } \\
\text { missing, no margins, severe spelling problems. }\end{array}$ \\
\hline \multirow{5}{*}{$\begin{array}{l}\text { Vocabulary (style of } \\
\text { quality of } \\
\text { expression) }\end{array}$} & 5 & $\begin{array}{l}\text { Excellent to good : precise vocabulary usage, use of } \\
\text { parallel structures, concise, register good. }\end{array}$ \\
\hline & 4 & $\begin{array}{l}\text { Good to adequate : Attempts variety, good vocabulary, not } \\
\text { wordy, register OK, style fair;y concise }\end{array}$ \\
\hline & 3 & $\begin{array}{l}\text { Adequate to fair : Some vocabulary misused, lacks } \\
\text { awareness of register, may be too wordy. }\end{array}$ \\
\hline & 2 & $\begin{array}{l}\text { Unacceptable-not : poor expression of ideas, problem in } \\
\text { vocabulary, lacks variety of structure }\end{array}$ \\
\hline & 1 & $\begin{array}{l}\text { College-level work : inappropriate use of vocabulary, no } \\
\text { concept of register or sentence variety. }\end{array}$ \\
\hline
\end{tabular}

Brown (2004)

\subsubsection{Techniques for Collecting Data}

In collecting the data in this study, the present researcher took the data from pretest and posttest. It was conducted from April $22^{\text {th to }}$ May $6^{\text {th }} 2018$ at SMK NW Pancor. The present 
researcher conducted the pretest on April 22 2018 ; it was given before treating the students. In the pretest the present researcher distributed the test and asked them to answer the question. It aims at finding out the students' prior knowledge in writing. Meanwhile, the treatments were conducted in 4 meetings; the researcher treated the students by applying snowball technique in teaching writing on recount text. The students were asked to write recount text based on their experiences. Afterwards, the present researcher conducted the posttest to students on May $6^{\text {th }}$ 2018. In this meeting, the researcher gave the test to the students and asked them to answer the question. The test was the same as pretest. The test was aimed at knowing the students' score after the treatment. This was to know the effectiveness of Snowball technique in teaching writing recount text.

\subsection{Data Analysis}

The technique of analyzing the data in this research was descriptive statistics. This technique aimed at finding out Mean Score and Standard Deviation of students' achievement test. The present researcher calculated the Mean Score and Standard Deviation of the experimental group by using (Statistic Package for Social Science) SPSS Statistical 22 for Windows. In testing hypothesis, the collected data should be normal and homogeneous. Both Normality Distribution and Homogeneity were tasted by using SPSS Statistical 22 for Windows. In calculating Normal Distribution, the present researcher used One-Sample Kolmogorov-smirnov test and Shapiro-walk test. If the values of the significance level of the investigated variables are greater than 0.05 , the distribution of the data is in normal and homogeneous. To prove whether the hypothesis of this research was accepted or rejected, the researcher used SPSS statistics 22 for windows to know the effectiveness of Snowball technique in teaching writing recount text, the researcher implemented paired- samples t-test in processing the obtained data. It was used because this study had the same variable on two different occasions for the same subject.

\section{Findings}

After analyzing the data, the researcher found the lowest and the highest score of pre-test and post- test. The detail data regarding the achievement of the students in the pretest are that 9 students (43\%) were categorized into "modest", 12 students $(57 \%)$ were categorized into "low". Thus, from the data, it can be concluded that the majority of students $(57 \%)$ still have problems and absolutely need to improve their writing ability.

Moreover, in the post-test further showed that the students writing skill was significantly improved. The detail data regarding the achievement of the students in the post-test are that 12 students (57\%) categorized into "high", 9 students (43\%) categorized into "modest". Thus, from the data, it can be proven if the students' writing skill were improved than before.

Furthermore, the result of the calculated data showed that the mean score of experimental group in the pre-test was 36.38 and in the post-test were 60.57. Meanwhile, the standard deviation of the pre-test was 11.16 and the post-test was 8.88. Based on the data gained on the students' writing skill, it was indicated that the mean score after having the treatment was higher than before having treatment. It meant that Snowball technique was effective in 
teaching writing skill. To be more clearly, the result of descriptive statistics can be seen in Table 2.

Table 2. The result of Mean Score and Standard Deviation

\begin{tabular}{llll}
\hline No & Activity & Mean & Std. Deviation \\
\hline 1 & Pre-test & 36.38 & 11.16 \\
2 & Post-test & 60.57 & 8.88 \\
\hline
\end{tabular}

In testing hypothesis, the collected data should be normal and homogeneous. There are two required statistics needed, namely Normal Distribution and Homogeneity. Both Normality Distribution and Homogeneity were tasted by using SPSS Statistical 22 for Windows. Based on the result of One-Sample Shapiro-Wilk, all of the values of Shapiro-Wilk in the pre-test and the post-test were higher than the values of the significant $(p)=0.05$. The value of Shapiro-Wilk in the pre-test was 0.053 while the value of significance in the post-test was 0.181. It implied that the data were in normal distribution. To be more clearly, the result of Normality testing can be seen in Table 3 .

Table 3. The Result of Normal Distribution of Shapiro-Wilk

\begin{tabular}{llll}
\hline Activity & Shapiro-wilk statistics & df & Sig. \\
\hline Pre test & .909 & 21 & .053 \\
Post test & .936 & 21 & .181 \\
\hline
\end{tabular}

Meanwhile, to test the homogeneity the researcher used One-Way ANOVA to measure wheter the data were homogeneous or not. Based on the calculation of One-Way ANOVA, the significant values in pre-test and post-test were 0.179. It meant that the data of this research were homogeneous. To be more clearly, the result of Homogeneity can be seen in Table 4.

Table 4. The Result of Homogeneity Levene Statistics Test of Homogeneity of Variances

\begin{tabular}{ccccc}
\hline & Levene Statistics & df1 & df2 & Sig. \\
\hline \multirow{2}{*}{ Prepost } & 1.873 & 1 & 40 & .179 \\
\hline
\end{tabular}

After knowing the data were normal and homogenous, the researcher used Paired Samples T-Test to get the hypothesis' answer. After performing a paired-samples t-test, the researcher found that there was a significant difference in the mean scores between the pretest and the post-test. The result of the paired sample t-test showed that the significance (2tailed) value level of the analyzed data was 0.00, and it was lower than 0.05 . This means that the alternatif hypothesis of this study was accepted. Thus, Snowball technique is significantly effective in teaching writing on recount text for the tenth graders of SMK NW Pancor in the school year 2017-2018.

\section{Discussion}


Snowball technique is a suitable technique to be applied in the classroom in teaching writing recount text. This technique helped the students to improve their writing ability. The students improved their self-confidence and reduced their anxiety through Snowball technique in writing process. By applying Snowball process, the students had appropriate behaviors in writing process. Regulating and problem solving in Snowball technique process had great effect in learning process toward completion writing task.

The goal of this study were to know whether or not Snowball technique is effective in teaching writing on recount text for the tenth graders of SMK NW Pancor in the school year 2017-2018 and to find out the extent effectiveness of Snowball technique in teaching writing on recount text for the tenth graders of SMK NW Pancor in the school year 2017-2018. This research was focused on treatment of the use of Snowball technique in teaching writing skill in EFL Classroom. The implementation of the treatment has positive result. It was proved through the activities conducted by the researcher which could increase student's interest in studying English especially writing recount text.

In addition, the application of Snowball technique was useful and interesting technique because it gave every student an opportunity to write their ideas. However, during the treatments, it was observed that there was some students' lack of practice in writing; they never have effort to do practice and keep their writing. But, after implementing Snowball technique in the classroom the students seemed to be active and participate to write. It was seen on the result of students' score was successful in achieving the learning objectives of SMK NW Pancor. Indeed, the average score after implementing Snowball technique was higher than before giving treatment. By good lesson plan, the teaching and learning process ran well. Therefore, the students' involvement increased when they studied by using Snowball technique. These findings support Istarani's statement about Snowball technique.

According to Istarani (2012) as cited in Henny Susanty states some advantages of Snowball technique are that Snowball technique can develop creativity of the students and it creates a lively classroom atmoshpere because all students must work in order to complete their tasks.

Based on the result of this research, the researcher found the same advantages of Snowball technique as Istarani. The researcher found that the students were more creative in putting their ideas about how to retell their experiences. All students worked in group to complete the tasks and share their ideas, and they were very active in participating to write because the researcher provided an interesting topic closed to students' realities. It was seen on how students enjoyed and active during learning process when they studied by using Snowball technique.

In summary, there are some points that make Snowball technique is effective in teaching writing on recount text. Those are students are more creative because all students worked in group to complete the tasks and share their ideas. The researcher also provided an interesting topic closed to students' realities, so they could work based on their knowledge and they can focus. The students were able to make paragraph recount text. The students had a plan for writing task that made the students able to solve their lack in writing process. Thus, it can be 
concluded that Snowball technique was effective in teaching writing skill especially in writing recount text.

\section{Conclusions}

Referring to the result of research, the researcher synthesizes briefly some conclusions. Those are: Snowball technique was effective in teaching writing on recount text to the tenth graders of SMK NW Pancor in the school year 2017- 2018, and Snowball technique was significantly effective in teaching writing on recount text to the tenth graders of $S M K N W$ Pancor in the school year 2017-2018. Concerning to the conclusions, the researcher would like to offer some suggestions. Those are: To other English teachers, using Snowball technique is a great way for students to learn writing recount text because it is easier to relate the lesson with the real condition to make students more focus in learning, so it is suggested that this technique is applied in teaching and learning process. Moreover, the English teachers should create a good atmosphere and try some teaching techniques that are suitable for the students in order to get students' attention as well interest. Headmasters should motivate and support their English teachers to choose appropriate technique, method, approach, and strategy in teaching writing. Further researchers should select an appropriate technique in conducting further investigation to find the main factors which can influence the students' ability, especially in students' writing ability.

\section{References}

Ayu Sonia. (2016). Students' reading techniques difficulties in recount text. Journal of English and Education. 4(2), 1-12. Retrieved from March 2, 2018, http://ejournal.upi.edu/index.php/.

Brown. (2000). Teaching by principles: an interactive approach to language pedagogy. San Francisco State University: Longman.

Brown. (2003). Language assessment principles and classroom practices. San Francisco, California: Longman.

Henny Susanti. (2016). Use of the snowball throwing technique for teaching better ESL speaking. English Education Journal, 7, 117-129. Retrieved from February 16, 2018, http://jurnal.unsyiah.ac.id

Moedjito. (2016). Basic statistics for research in language education. Surakarta: Yuma Pustaka.

Sugiyono. (2011). Metode penelitian pendidikan: pendekatan kuantitatif, kualitatif dan R\&D. Bandung: Alfabeta.

Urquhart and Monette Mclver. (2005) . Teaching writing in the contest area. Association for Supervision and Curriculum Development, Mid-continental Research for Education and Learning: Alexandria, Virginia USA, Aurora, Colorado USA. 